\title{
Fungal and Bacterial Biodeterioration of Outdoor Canvas Paintings: The Case of the Cloisters of Quito, Ecuador
}

\author{
Fernando Poyatos-Jiménez, ${ }^{\mathrm{a}, \mathrm{b}, *}$ Fátima Morales, ${ }^{\mathrm{a}, \mathrm{c}, *}$ Rosa Morales-Carrera, ${ }^{\mathrm{d}}$ Silvia Boffo, ${ }^{\mathrm{a}}$ \\ Antonio Giordano, ${ }^{\text {a }}$ \& Julio Romero-Noguera ${ }^{\mathrm{b}, *}$ \\ aSbarro Institute for Cancer Research and Molecular Medicine, Department of Biology, Temple University, \\ Philadelphia, Pennsylvania, USA; ' Department of Painting, Faculty of Fine Arts, University of Seville, Spain; \\ 'Department of Preventive Medicine and Public Health, University of Seville, Spain; 'Department of Microbiology, \\ School of Engineering Sciences and Industry, UTE University, Quito, Ecuador \\ *Address all correspondence to: Fernando Poyatos-Jiménez and Julio Romero-Noguera, Dpto. Pintura, Facultad de Bellas Artes, Universidad de \\ Sevilla, c/ Laraña 3, 41003 Sevilla, Spain; Tel.: +34954488176; Fax:+34954487763, E-mail: fpoyatos1@us.es; juliorn@us.es; or Fátima Morales \\ Marín, Dpto. Medicina Preventiva y Salud Pública, Facultad de Medicina, Universidad de Sevilla, Avda. Doctor Fedriani, s/n, 41009 Sevilla, \\ Spain; Tel.: +34954551771; Fax: +34954559827, E-mail: fmmarin@us.es
}

\begin{abstract}
The historic center of Quito, Ecuador, was one of the first World Cultural Heritage Sites declared by UNESCO in 1978. There are numerous religious buildings built during the Spanish colonial period reflecting the cultural heritage in this area. Between them, the cloisters of San Francisco, Santo Domingo, and Santa Clara should be highlighted. The specific problems of conservation of the outdoor canvas paintings are not well known at the moment. The objective of this paper is to achieve a conservation study of the canvas paintings exhibited in these three cloisters of the historic center of Quito in order to identify the microbial agents and the main bioclimatic parameters of deterioration. For this, a study of the state of conservation of five canvas paintings has been carried out, as well as a sampling and identification of the main microorganisms present on the obverse and reverse of the works, employing diverse techniques, traditional and biomolecular ones. An analysis of climatic conditions has also been achieved in the cloister of San Francisco. The results of the study indicate that the exhibition conditions in the cloisters are really problematic for the conservation of paintings. Important biodeteriorating agents have been isolated, including fungi and bacteria species belonging, among others, to the genera Bacillus, Penicillium, Alternaria, Mucor, and Aspergillus. We have also researched its relationship with the deterioration state of the artworks and the exhibition conditions in each case, proposing guidelines for the proper conservation of this important World Cultural Heritage.
\end{abstract}

KEY WORDS: biodeterioration, canvas painting, cloisters, conservation, Quito

\section{INTRODUCTION}

The historic center of the city of Quito, Ecuador, was declared UNESCO World Heritage Centre in 1978. Numerous buildings built during the Spanish colonial period stand out, responding to urban settlements that the different religious orders were creating throughout the centuries, holding an invaluable material heritage. One of the particularities of the ensemble is the exhibition of cultural assets in the cloisters, with important pictorial series, as well as altarpieces, mural paintings, sepulchres and stone sculptures.

The cloisters are spacious and illuminated places, which has frequently led religious institutions to the exhibition and relocation in these spaces of works of art and complete pictorial series, such as those dedicated to the Lives of the Saints (Fig. 1).

Of particular interest are those belonging to the convents of San Francisco, Santo Domingo and Santa Clara, located in the southern area of the historic center (Fig. 2), where works of great quality, diverse origin and state of conservation are exposed. ${ }^{1-3}$ In the colonial paintings of Quito, it is difficult to establish homogeneous technical, artistic and stylistic features that respond to the existence of a local pictorial school, as happens with sculpture. The existing documentation regarding the works is also scarce, as a reflection of the little consideration of this pictorial creation received in the past. ${ }^{4,5}$

The diverse typologies of cultural heritage exposed in these spaces are affected by deterioration 

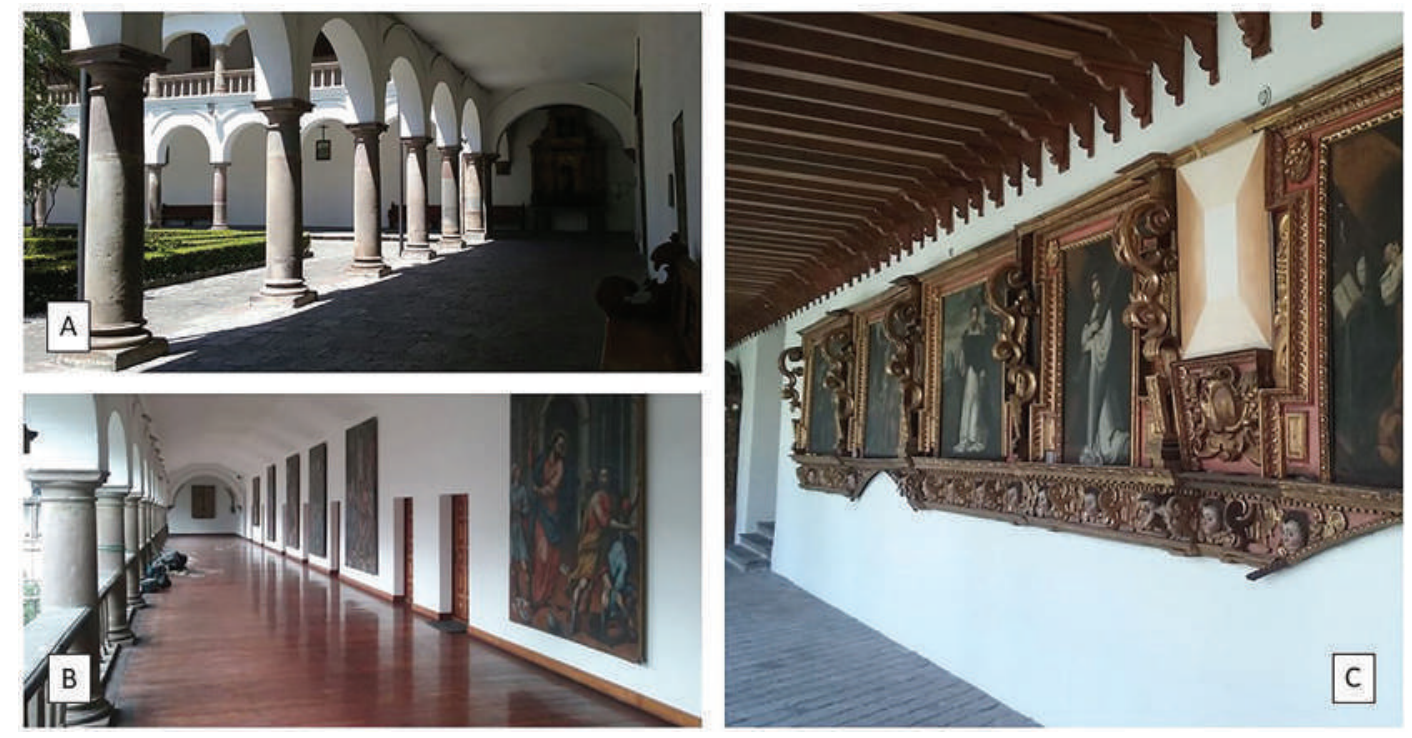

FIG. 1: Cloister of San Francisco Convent (A, B) and Santo Domingo Convent (C)

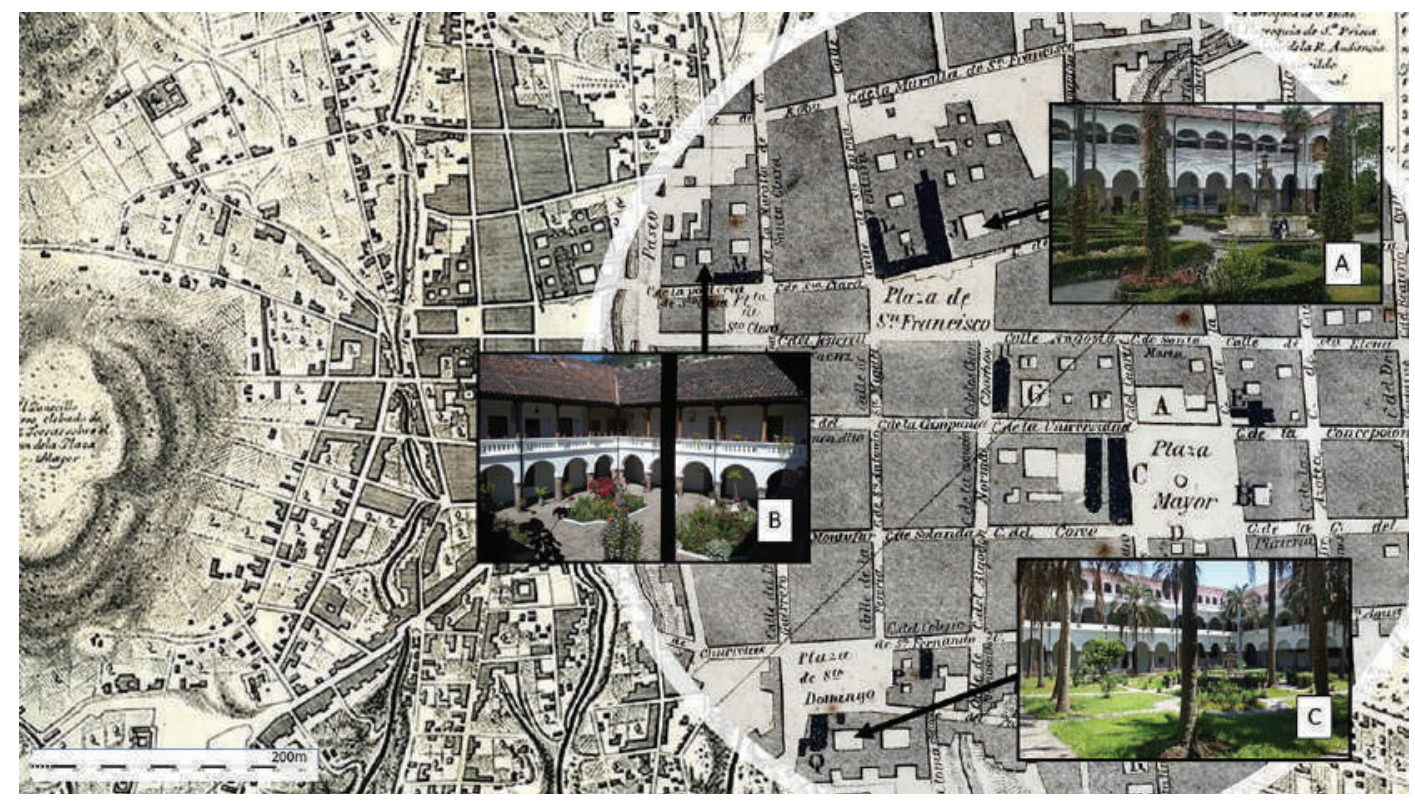

FIG. 2: Details of the historic center of Quito. Shown is the location of the three cloisters of the research: San Francisco (A), Santa Clara (B), and Santo Domingo (C).

factors. The most important ones are environmental conditions, illuminance, human deterioration and the ones caused by biological agents. ${ }^{6-8}$

The climate of Quito is called equatorial or subtropical of high lands and it is mild throughout the year. It is characterized by the high contrast between the day and night, with maximum and minimum temperatures ranging from 10 to $27^{\circ} \mathrm{C}$, with an annual average of $15^{\circ} \mathrm{C}$. There is a rotation between a dry and a wet season, in which there are frequent relative humidity $(\mathrm{RH})$ peaks in the form of torrential rain. The dry season runs from June 
to September. Temperatures rise somewhat more than the rest of the year, hovering around $20^{\circ} \mathrm{C}$ of maximum average temperature, with peaks that can rarely reach $30^{\circ} \mathrm{C}$. During the nights, the temperatures drop sharply, with the minimum being $9^{\circ} \mathrm{C}$.

The wet season goes from October to May, with mild temperatures of around $14^{\circ} \mathrm{C}$, maximum of $19^{\circ} \mathrm{C}$ during the day and $8^{\circ} \mathrm{C}$ during the night. Although Quito is 2850 meters above sea level (MASL), it almost never snows in the city. According to data from the National Institute of Meteorology and Hydrology of Ecuador (INAMHI) collected during the years 2006 to 2010, the average monthly maximum RH in each year was very high, $79 \%$, and the minimum was $59 \%$. The maximum absolute $\mathrm{RH}$ registered throughout the period was $100 \%$ and the minimum was $22 \%$. With regard to the exhibition of pictorial works of art, the environmental conditions described pose a double risk, since they combine high RH levels with large daily and seasonal fluctuations. . $^{3,9,10}$

In pictorial artwork, the biodeterioration processes are often induced by insects, Microchiroptera, fungi, and bacteria. ${ }^{11,12}$ Important studies have been published, trying to determinate the microbial diversity associated to mural paintings and frescoes. ${ }^{13-17}$ However, the works dedicated to canvas or wood painting are more scarce, ${ }^{18-27}$ because it becomes more difficult to get information about the scope of these processes in easel paintings exhibited in outdoor environments.

The main factors responsible for the growth of microorganisms in paintings are the chemical composition of the artwork, the availability of nutrients and the environmental conditions, highlighting as essential factors the levels of RH and water activity. ${ }^{28}$ The effects of microbial biodeterioration in pictorial artwork can be observed in both sides: the obverse and reverse. ${ }^{29}$ Canvas paintings present diverse materials that can be altered by microorganisms. Apart from the lipid components of the pictorial layer, there are protein materials in its preparation layer (animal glues), cellulose in the support (canvas or wood) and generally terpenic natural varnishes in the protection layer.

They can also respond to mix techniques, such as egg tempera, that holds an additional protein component, or even containing new natural or synthetic polymeric materials in works that have been restored. Normally, the deterioration of the canvas oil paintings begins on the reverse, as a consequence of the easier biodegradation of the support, the presence of other nutrients and the existence of a microclimate of higher RH because of the contact with walls or wet and cold surfaces. Only under conditions of high RH maintained over time, the biodeterioration could begin on the pictorial surface. ${ }^{13}$

Fungal growth can cause the deterioration of the pictorial layer as the hyphae penetrate through the layers of the canvas, ${ }^{30}$ a process that is aggravated (not only in fungi, but also in the case of bacterial biodeterioration patterns) by the excretion of metabolites such as organic and inorganic acids and the production of extracellular enzymes, which lead to the deterioration of materials and the separation and loss of pictorial layers, preparation layer, varnish and support, as well as discolorations and the appearance of stains. ${ }^{13,10,31}$ The main enzymatic activities involved in the deterioration of paintings caused by microorganisms are due to: i) enzymes of glucosidase activity, that affect to the support, ii) lipases, which catalyze hydrolysis of ester bonds of triacyl-glycerols at the interface between an insoluble substrate and water, ${ }^{32}$ iii) esterases, which act only on water-soluble substrates, ${ }^{32}$ iv) endo-N-acetyl-glucosaminidases acting on murein or chitin, and $\mathrm{v}$ ) proteases.

The knowledge of the microbiota and environmental conditions is important for the proper conservation of the pictorial artwork, as well as to choose the most appropriate suitable restoration methods. ${ }^{19,21,22,30,33,34}$ The objective of this research is to provide information about the agents of deterioration that affect this particular type of exhibited artwork (canvas paintings), and its relationship with the environmental conditions. For that, a follow-up has been carried out to know the main bioclimatic parameters in the cloisters of Quito: RH, temperature, and their daily and seasonal changes. We have selected five pictorial artworks which are representative of the ensemble, where we have identified fungi and bacteria by conventional and molecular biology methods, in order to obtain a fingerprinting of the regular microbiota in this environment, and we have put it in relation with the exhibition conditions. The information obtained has been compared 
with the recommendations of the international institutions for the preventive conservation of canvas paintings. General recommendations have been proposed to improve the preservation of this important typology of cultural heritage.

\section{MATERIALS AND METHODS}

\section{A. Studied Paintings}

The studied artworks respond to diverse artistic moments, being carried out by different artists, whose technique we could place chronologically from the second half of the seventeenth century to the end of the eighteenth century. The artistic quality of the paintings is also uneven, although the aspect that we are most interested in evaluating is their material constitution. They are painted on canvas, following the usual work process of the time: a preparation base made of animal glue and inorganic materials, such as plaster and calcite, with the pictorial stratum over, composed of linseed oil and pigments, and finally a protective terpenoid varnish. The artworks are the following (Table 1):

- "Appearance of the Virgin in the Porciúncula" (SF1) Convent of San Francisco. Canvas painting. $205 \times 271 \mathrm{~cm}$. XVIII century (Anonymous).

- "The Entrance of Jesus in Jerusalem" (SF2) Convent of San Francisco. Canvas painting. $310 \times 208 \mathrm{~cm}$. XVIII century (attributed to Bernardo Rodríguez).

- "San Francisco de Asís" (SD1) Convent of Santo Domingo. Canvas painting. $176 \times 216$ $\mathrm{cm}$. XVII century (Anonymous).

- "Ecstasy of Saint Teresa" (SD2) Convent of Santo Domingo. Canvas painting. $177 \times 212$ $\mathrm{cm}$. XVII century (Anonymous).

- "Divine Pastor" (SC1) Convent of Santa Clara. Canvas painting. $191 \times 290 \mathrm{~cm}$. XVIII century (Anonymous).

Of these five paintings, four are currently exhibited in cloisters and a fifth was only until recently. This is the canvas SF1, which is currently housed in one of the internal corridors of the Convent of San Francisco, while the work "The Entrance of Jesus in
TABLE 1: Obverse, reverse, and sampling areas of the studied artworks

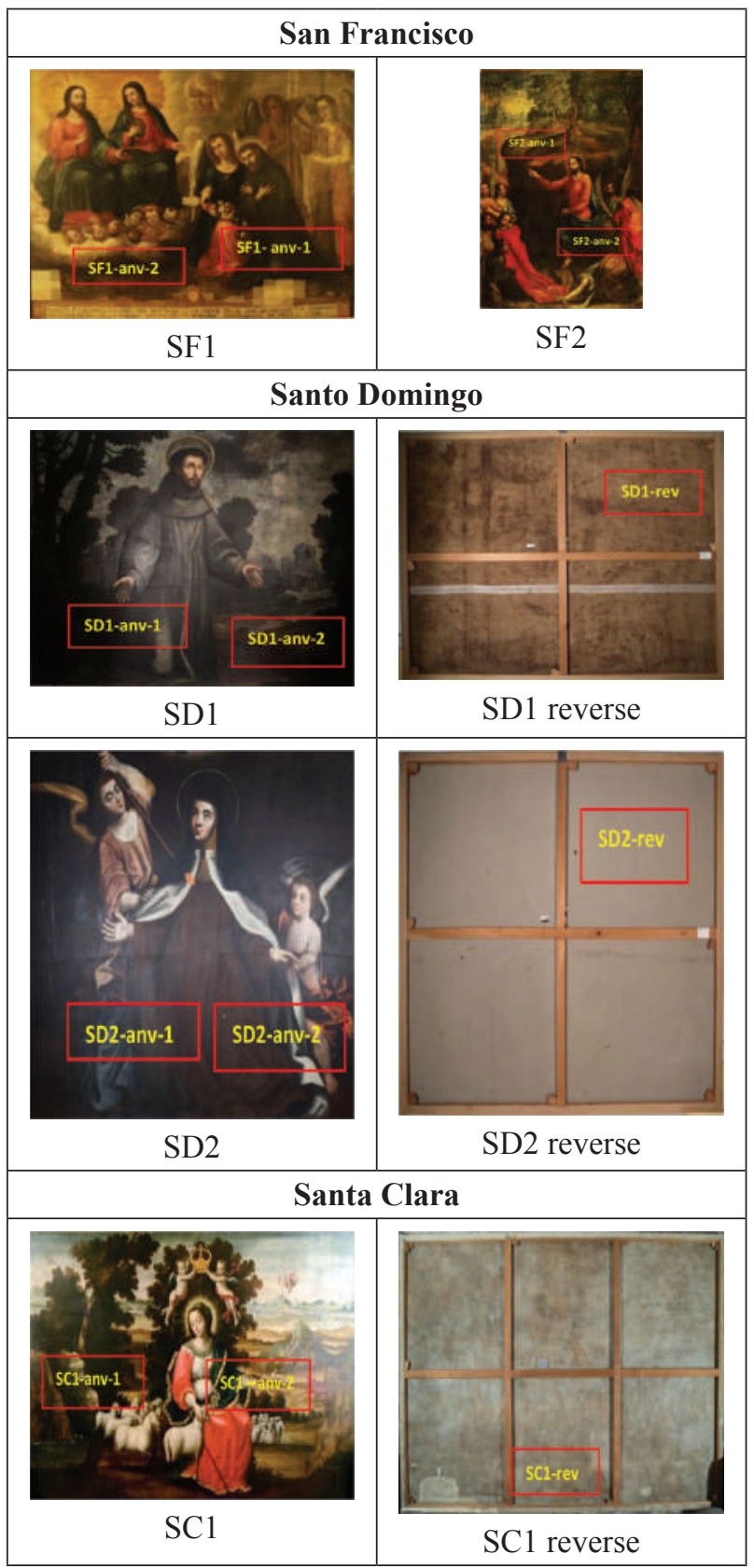

Jerusalem" (SF2) is located in the upper north wing of the main cloister of this building. The works exhibited in Santo Domingo are exhibited in the south and west wings of the cloister, and the painting of the Convent of Santa Clara "Divine Pastor" (SC1) is also found outside, on the access stairway to the main cloister (Fig. 3). 


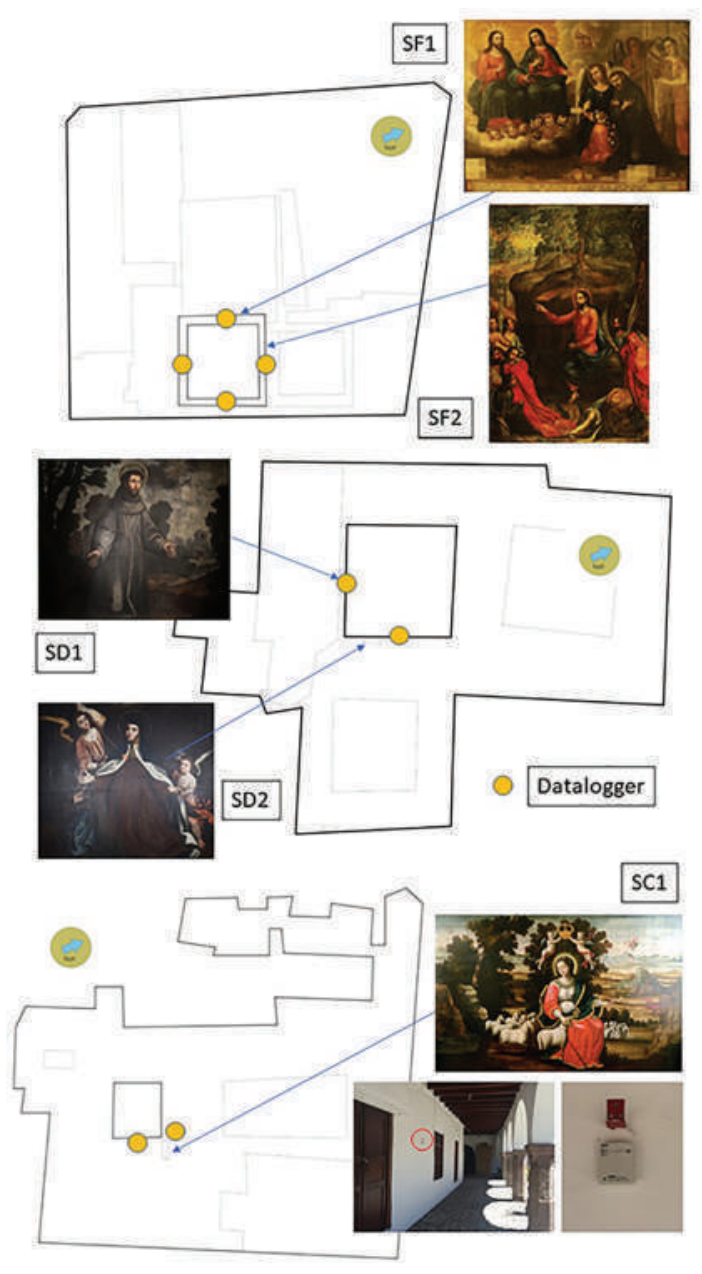

FIG. 3: Location of the studied artwork in the cloisters and data loggers

\section{Historic-Artistic Characteristics and Conservation State of the Paintings}

In order to know the history of the analyzed artworks, analog and digital databases were consulted, such as the Historical Archive of the National Institute of Historical Heritage of Ecuador (INPC) ${ }^{35}$ and the institutional archives of religious institutions.

For the study of the materials, the paintings were removed from their location and an organoleptic examination and documentation were carried out with standard techniques: visible photography, grazing light photography (GLP) and observation with an ultraviolet fluorescence lamp (UVF).
The GLP study was carried out with oblique lighting from an $18 \mathrm{~W}$ LED light source at an angle of $5^{\circ}$ to $30^{\circ}$, which enabled surface roughness or irregularities to be seen, so that an expert eye could evaluate the paintings. To document the analysis, we used a Canon digital IXUS 8015 camera with a $6.2-18.6 \mathrm{~mm}$ focal length. Examination with ultraviolet light was performed with a UV lamp $60 \mathrm{~W}$ VL-215M, coupled with fluorescent tubes (15 W of UV lighting within a range of $270-380 \mathrm{~nm}$, attaining an illuminated surface area of $8 \mathrm{~mW} / \mathrm{cm}^{2}$ ).

\section{B. Monitorization of Environmental Conditions}

The evaluation of the environmental conditions of the exhibited artworks has been achieved following the protocols proposed by Gil and Enríquez ${ }^{36}$ and Villamar. ${ }^{37}$ The Technological Equinoctial University collaborated in this project, carrying out the study. Onset Hobo U12-012 12-bit Data-Logger remote sensors were used, programmed to measure temperature $\left({ }^{\circ} \mathrm{C}\right), \mathrm{RH}(\%)$ and illuminance (lux) that were located on the north, south, east, and west walls of the courtyard of the main cloister of the San Francisco Convent, at a height of $2.66 \mathrm{~m}$ and close to the studied paintings (Fig. 3 ). Measurements were carried out over a 6-month period, from mid-September 2014 to mid-March 2015, with measurement intervals every 15 minutes. The obtained data of the cloister of San Francisco is considered representative of the climatic conditions of all the studied paintings as they are held in similar conditions in the other two cloisters (Santa Clara and Santo Domingo).

\section{Microbiological Study}

\section{Sampling}

For this study, we selected a non-invasive sampling technique ${ }^{38}$ based on the use of a sterile cotton swab to rub the obverse and reverse surfaces of the artworks. Specifically, we collected sample in areas of $20 \mathrm{~cm}^{2}$ with buffered peptone water (Merck, Spain) in zones where signs of alteration compatible with biodeterioration patterns 
were observed, such as changes in the colors of the painting, the appearance of stains or variations in the structure of the painted layer, both on the obverse and reverse of the five easel paintings under study (Fig. 4).

\section{Isolation of Microorganisms}

All the samples collected from the easel paintings were analyzed for microorganism (bacteria and fungi) identification. The isolated bacteria were studied by polymerase chain reaction (PCR). In the case of fungi, traditional morphological identification was performed, except in four uncertain cases, in which molecular techniques were used.

Bacterial isolation was performed by pouring $1 \mathrm{~mL}$ of each sample on Petri dishes of Nutrient agar (Merck, Spain). This medium provides carbon, nitrogen and mineral salts, supporting the growth of a wide range of non-fastidious bacteria that could grow on the studied paintings. Petri dishes were incubated at $37^{\circ} \mathrm{C}$ for 18 hours. After that, we achieved the counting and isolation of the diverse morphological colonies according to the methodology recommended by the U.S. Food and Drug Administration (2020).
In the case of fungi, the isolation was carried out by pouring $1 \mathrm{~mL}$ of each sample into a Petri dish of Sabouraud chloramphenicol agar (Merck, Spain). They were incubated at $25^{\circ} \mathrm{C}$ for 15 days, after which the morphologically different colonies were counted and isolated. The identification of the isolated colonies was carried out by traditional and molecular biology techniques. We evaluated the kinetic growth of the colonies at different temperatures: $20^{\circ} \mathrm{C}, 25^{\circ} \mathrm{C}, 30^{\circ} \mathrm{C}$, and $35^{\circ} \mathrm{C}$, staining with lactophenol blue to analyze the morphological structures with the microscope, and comparing them with literature data about specific morphological characteristics. ${ }^{39,40}$

The cultures were observed daily to monitor the colony growth. After microorganism isolation, bacteria were grown in trypticase soy agar (TSA, Merck, Spain) and fungi in potato dextrose agar (PDA, Merck, Spain). All microorganisms were conserved in $70 \%$ glycerol at $-80^{\circ} \mathrm{C}$.

\section{DNA Extraction}

Genomic DNA from pure bacterial strains was extracted following the procedure described by Schabereiter-Gurtner et al., ${ }^{30}$ which relies on a
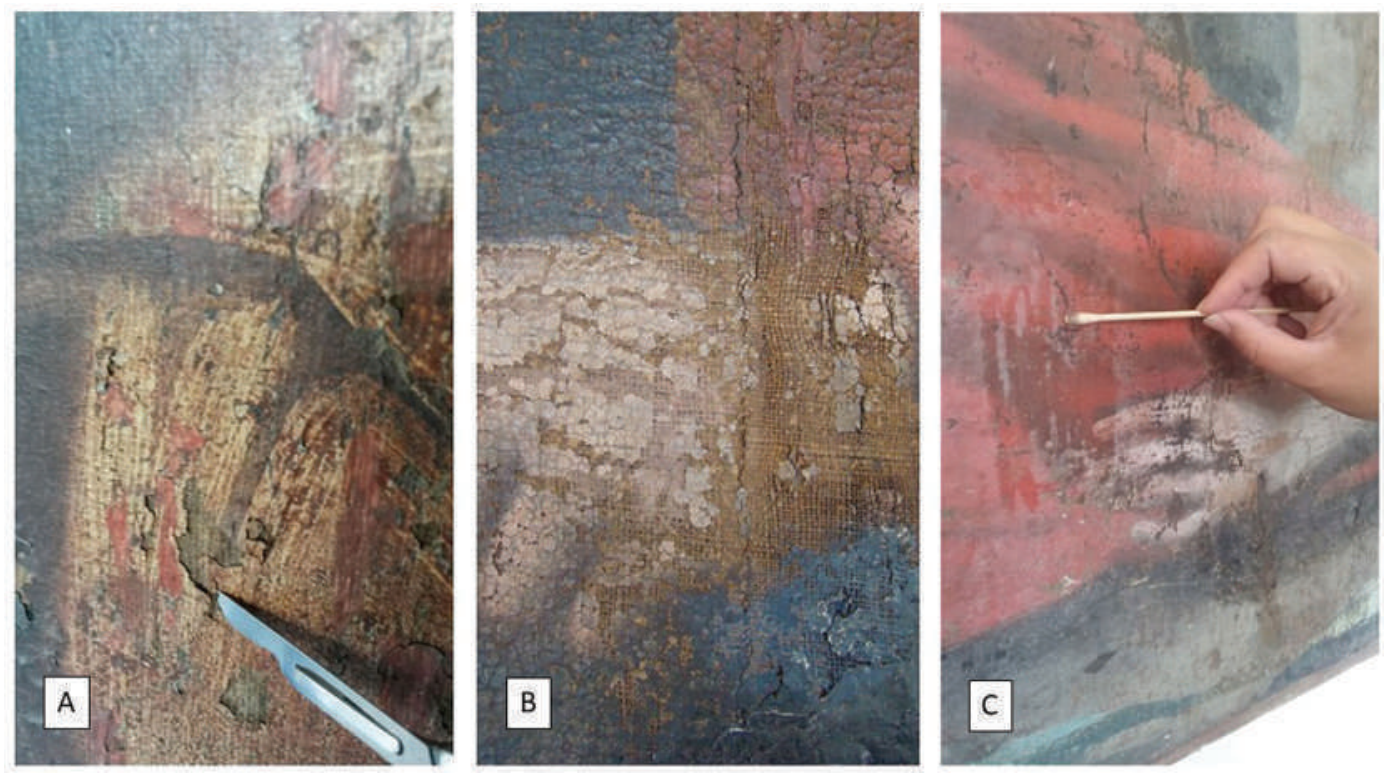

FIG. 4: Sampling areas of the artworks SD2 (A) and SF2 (B, C) 
chemical disruption of cells, the removal of cell wall debris, polysaccharides, and proteins by precipitation with CTAB (cetyl trimethylammonium bromide), and the recovery of the DNA by ethanol precipitation.

DNA extraction of pure fungal strains was performed according to the procedure described by Sert and Sterflinger, ${ }^{41}$ based on chemical and mechanical disruption of cells and the recovery of DNA by ethanol precipitation. Specifically, we vortex $1 \mathrm{~cm}^{2}$ of mycelium or bacteria $+500 \mu \mathrm{L}$ of lysis buffer for $3 \mathrm{~min}$ and for $1 \mathrm{~h}$ at $65^{\circ} \mathrm{C}$ in the water bath. They were vortex again for $3 \mathrm{~min}$ and centrifuged at $12,000 \mathrm{rpm}$ for $15 \mathrm{~min}$. The supernatant was kept cleaned with the MiniKit High Pure Plasmid Isolation Kit (MiniKit, Roche ${ }^{\circledR}$ ) following the protocol of the manufacturer. The quantity of DNA was measured with the Nanodrop System (Thermo Scientific ${ }^{\circledR}$ NanoDrop 2000 Spectrophotometer).

\section{PCR Amplification}

PCR reaction of DNA was performed in $25 \mu \mathrm{L}$ volumes of a reaction mixture containing $1 \mu \mathrm{L}$ of each primer, $2.5 \mu \mathrm{L} \mathrm{MgCl}_{2}, 0.5 \mu \mathrm{L}$ dNTP $200 \mathrm{mM}$ of each deoxyribonucleoside triphosphate, $5 \mu \mathrm{L}$ of $5 \mathrm{X}$ PCR buffer, $0.12 \mu \mathrm{L}$ of Taq DNA Polymerase, $2 \mu \mathrm{L}$ of the DNA extraction and made up to $25 \mu \mathrm{L}$ with sterile water.

Primers used for the bacterial were $341 \mathrm{f}$ and $907 \mathrm{r}$, identifying the fragments corresponding to nucleotide positions of the Escherichia coli 16S subunit. ${ }^{30}$ For fungi, we used four combinations of the universal primers used for fungal amplification: ITS1-ITS4, ITS1-ITS2, ITS5-ITS2, and ITS3-ITS4. ${ }^{42}$

For the amplification of fungal ITS regions, fragments of 450-600 bp in size, corresponding to the ITS 1 and the ITS2 regions, and the 5.8S rRNA gene situated between them, were amplified with the primer pairs ITS1 forward and ITS4 reverse. ${ }^{42}$

We performed the DNA amplification with the following thermocycling conditions: $10 \mathrm{~min}$ denaturation at $94^{\circ} \mathrm{C}$, followed by 40 amplification cycles of 1 min denaturation at $94^{\circ} \mathrm{C}, 1 \mathrm{~min}$ primer annealing at $60^{\circ} \mathrm{C}$, and 1 min primer extension at $72^{\circ} \mathrm{C}$, to end with a final extension step of $10 \mathrm{~min}$ at $72^{\circ} \mathrm{C}$.

The genetic fingerprints of the microorganisms were analyzed by Nested-PCR, using similar conditions as before. The combinations of primers this time were: $341 \mathrm{f}-\mathrm{GC}$ and $518 \mathrm{r}$ for bacteria, ${ }^{30}$ and ITS1-GC with ITS2 for fungi. ${ }^{42}$ The total volume of each reaction was $50 \mu \mathrm{L}$. The mix contained 2 $\mu \mathrm{L}$ of each primer, $5 \mu \mathrm{L} \mathrm{MgCl}_{2}, 1 \mu \mathrm{L}$ dNTP 200 $\mathrm{mM}$ of each deoxyribonucleoside triphosphate, 10 $\mu \mathrm{L}$ of $5 \times$ PCR buffer, $0.25 \mu \mathrm{L}$ of Taq DNA Polymerase, $4 \mu \mathrm{L}$ of the DNA extraction and made up to $50 \mu \mathrm{L}$ with sterile water. The thermocycling conditions were: $5 \mathrm{~min}$ denaturation at $94^{\circ} \mathrm{C}$, followed by 35 amplification cycles of $1 \mathrm{~min}$ denaturation at $94^{\circ} \mathrm{C}, 1 \mathrm{~min}$ primer annealing at $60^{\circ} \mathrm{C}$ and $1 \mathrm{~min}$ primer extension at $72^{\circ} \mathrm{C}$, to end with a final extension step of $5 \mathrm{~min}$ at $72^{\circ} \mathrm{C}$. Nested-PCR products were electrophoresed in 3\% agarose gel, containing ethidium bromide for $0.5 \mathrm{~h}$ at $100 \mathrm{~V}$ in TBE buffer. The amplicons were purified using the Zymoclean Gel DNA Recovery Kit.

\section{Sequencing and Phylogenetic Analysis}

The cycle sequencing reactions were performed in $12-\mu \mathrm{L}$ volumes containing $100 \mathrm{ng}$ of DNA, $3.2 \mu \mathrm{M}$ of primer, and made up to $12 \mu \mathrm{L}$ with sterile water. Sequencing primers were $518 \mathrm{r}$ for bacteria and ITS2 for fungi. The sequencing was performed by Genewiz $^{\circledR}$ Company (South Plainfield, NJ, USA). The sequences obtained were compared with the database of the National Centre for Biotechnology Information (BLAST) (Bethesda, MD) ${ }^{43}$

\section{RESULTS AND DISCUSION}

\section{A. State of Conservation}

Table 2 shows the technical aspects that determinate the current conservation state of the artworks. Some of the observed alterations are compatible with the existence of biodeterioration patterns in synergy with incorrect levels of illuminance, $\mathrm{RH}$ and temperature that have caused the physical-chemical alterations of binders and varnishes, as well as the weakening of cellulose textile fibers. 


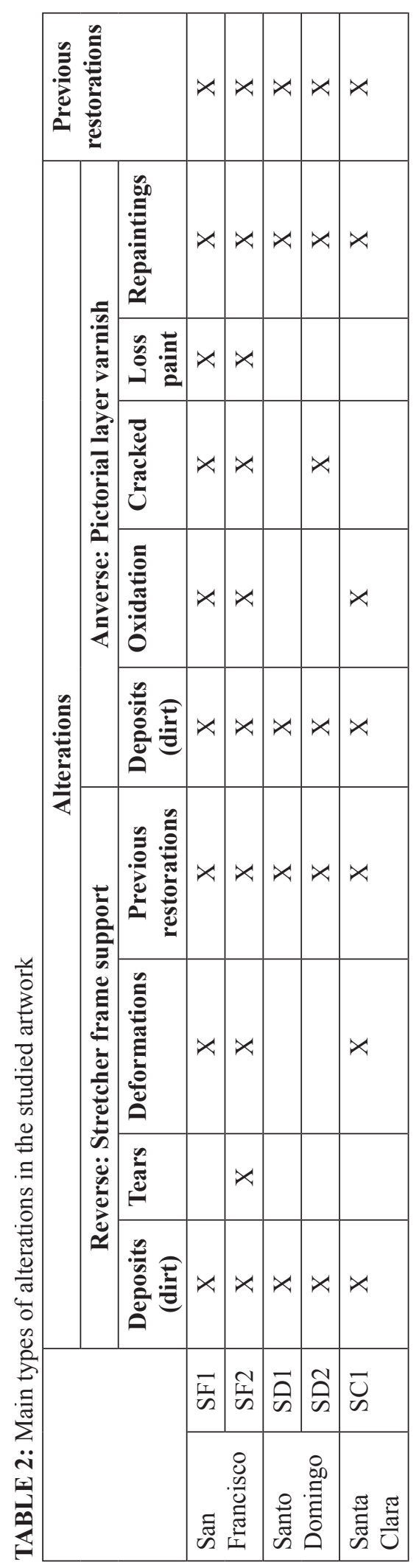




\section{Convent of San Francisco}

The studied artworks present different states of conservation as a consequence of their exposure to the outside and some unfortunate interventions of restorarion, which have favored the observed deterioration processes. In relation to the alterations produced by environmental agents, it is necessary to highlight the action of ultraviolet and visible radiation, which has produced the generalized discoloration of pigments, the lack of cohesion of the pictorial layers due to photochemical deterioration of the binders, and the total loss of the layers of protective varnish.

In the supports, we can observe a high degree of aging of the textile fibers, with evident loss of flexibility and resistance. In the case of SF1, the type of ligament employed ("mantelillo") helps to its durability, as it provides more resistence. We did not get samples from the reverse side of SF2 because of a lining applied with synthetic materials. In general, the lack of maintenance and periodic cleaning is also noteworthy, especially on the back of the artworks, where dust and dirt accumulate (Fig. 5). The SF2 work is placed in a very windy corridor, which generates sudden movements in the painting and favors the deposit of fungal spores. All these factors enhance both the presence of microorganisms and their ability to alter pictorial materials, which are much more easily attacked by fungi and bacteria due to the previous degradation conditions of the artworks. ${ }^{8}$

\section{Convent of Santo Domingo}

The deterioration patterns observed in the Convent of San Francisco recur in this cloister. The artworks located in the main cloister have been protected of direct sun light by a sunshade system in the south and southeast wings (Fig. 6). Despite the good intentions of these interventions, which are unfortunately taking place in many historical buildings in recent years, they can pose a serious risk to the exposed artworks. Moreover, a preliminary survey of the environmental parameters is essential, since they can favor other types of alterations, such as the retention of humidity by reducing ventilation, or an increase in temperature. So, the risk of alterations by radiation is changed by the risk of damage by moisture, corrosion and biodeterioration. Remains of Microchiroptera and various bird droppings can be seen on the obverse and reverse of the studied works, which can also favor the growth of microorganisms.
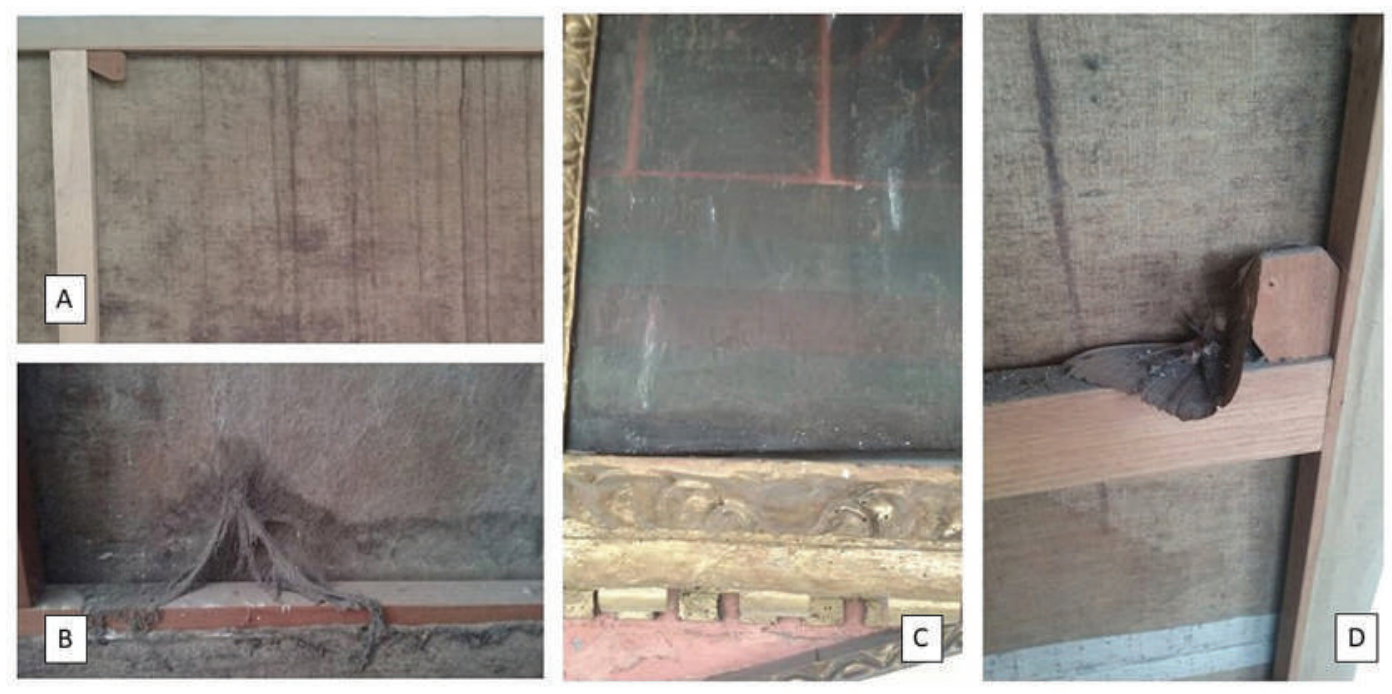

FIG. 5: (A) Bird excrement, reverse SD1, Convent of Santo Domingo. (B) Arachnid nest, reverse SC1, Convent of Santa Clara. (C) Bird droppings in pictorial surface, Convent of Santo Domingo. (D) Rest of lepidopterous insects, reverse SD1, Convent of Santo Domingo. 

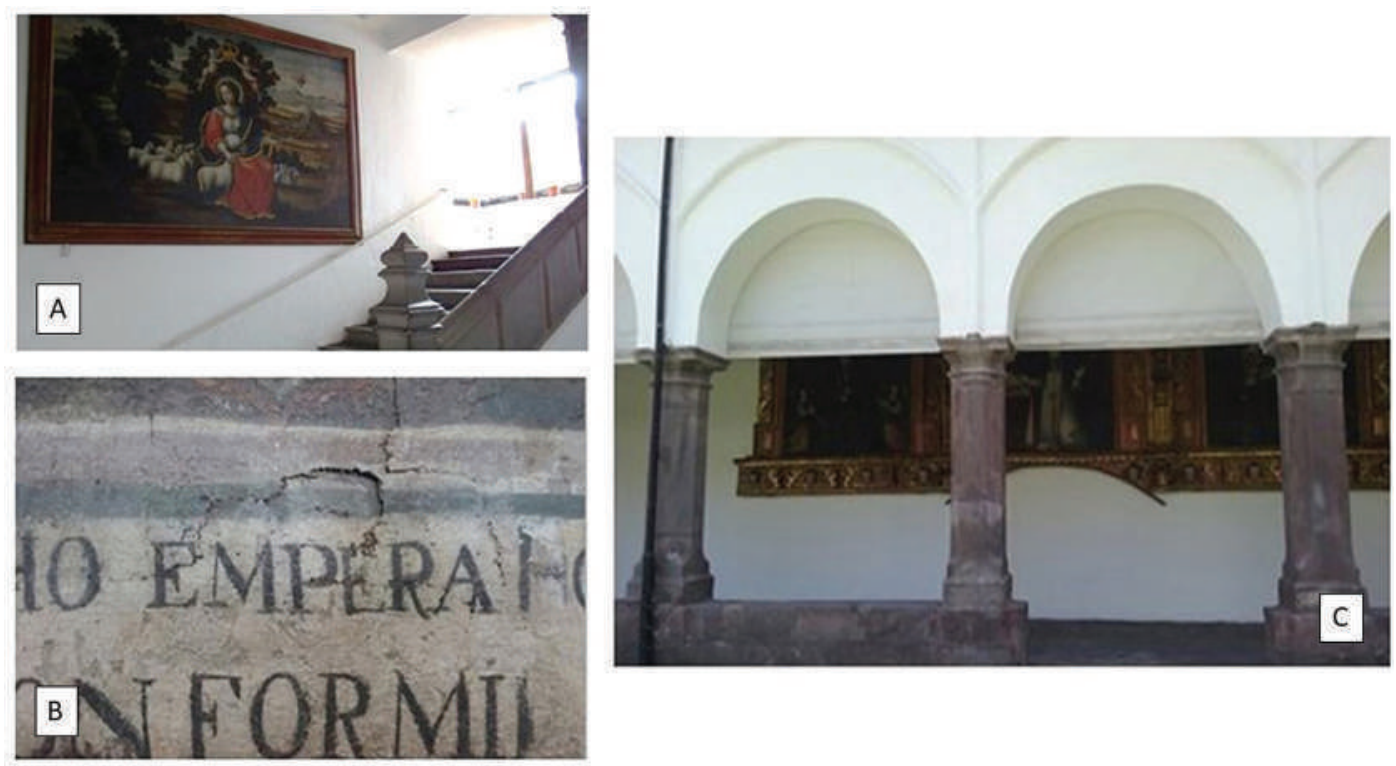

FIG. 6: (A) Location of the painting SC1. (B) Details of the damage caused by sunlight in the pictorial materials and polycromy in SF1. (C) Sunshade system installed in the cloister of Santo Domingo.

\section{Convent of Santa Clara}

The work SC1, exhibited on the staircase that leads to the upper cloister, presents a large amount of dust and dirt accumulated on the back as the main affection linked to biodeterioration. It is a large-format canvas well preserved in terms of its pictorial layers due to the lack of light on it surface directly (Fig. 6). However, we can observe arachnid nests and some restoration interventions, which have added new materials to the original support, on the reverse side. This canvas painting is the best preserved of the five studied and the one that holds the best exhibition conditions.

\section{B. Environmental Study}

According to the main international organizations dedicated to preventive conservation, the adequate environmental RH for a canvas painting should be in a range of $40-60 \%$, with maximum fluctuations of $25 \%$, while the values of temperature should be above $5^{\circ} \mathrm{C}$ and below $25^{\circ} \mathrm{C} .44,45 \mathrm{~A}$ limit value of $75 \% \mathrm{RH}$ is usually established, ${ }^{46}$ above which the risk for works due to biodegradation and corrosion is multiplied exponentially. Thus, the time for fungal proliferation is two months at $75 \% \mathrm{RH}$ and $18^{\circ} \mathrm{C}$, and only about 2 days at $90 \% \mathrm{RH} .{ }^{47}$ Fluctuations in $\mathrm{RH}$, especially those above $25 \%$, are also undesirable for objects containing layers of moisture-sensitive materials, a category that includes most canvas paintings. ${ }^{8}$

The conclusions of the environmental study ${ }^{37}$ indicate that the paintings are subjected to inadequate $\mathrm{RH}$ levels with respect to these recommendations. The average $\mathrm{RH}$ in the courtyard of the main cloister of the Convent of San Francisco was $65.24 \%$. It is in the maximum limit of the recommendations, and $15.25 \%$ higher from the ideal rate of $50 \%$. In most of the measurements $(65.78 \%)$, the RH was higher than $60 \%$, and only $42.74 \%$ of the time it was lower than $50 \%$.

Additionally, the fluctuations of RH were really important, exceeding the $25 \%$ established as the maximum admissible limit for this type of works. The average maximum RH was $86.54 \%$ and the minimum was $28.22 \%$. The maximum $\mathrm{RH}$ registered concerned to the south ground floor of the Convent, with a value of $90.17 \%$, while the minimum RH was observed in the west ground floor, with a value of $25.10 \%$. No major changes have been registered in the $\mathrm{RH}$ and temperature 
values between the different spaces of the cloister depending on their orientation. The wing with the highest average $\mathrm{RH}$ was the east ground floor $(67.07 \%)$, while the west ground floor shows the lowest average RH, with $63.76 \%$, both very similar.

The average temperatures are mild and they are in the range of the recommended values for the exhibit artwork, ${ }^{47}$ although the minimum recorded were relatively high, which favors biodeterioration processes, which slow down at low temperatures. The average temperature in the courtyard of the main cloister of the San Francisco Convent was $15.65^{\circ} \mathrm{C}$, with a mean maximum temperature of $23.27^{\circ} \mathrm{C}$ and $10.80^{\circ} \mathrm{C}$ of the minimum, with small variations depending on the orientation of the artworks in the cloisters. Another similar study carried out in the neighboring cloister of the San Agustín convent during the months of March to July $2013^{48}$ indicates that the average monthly maximum $\mathrm{RH}$ was $64.7 \%$, and the minimum was $32.7 \%$. The average maximum temperature was $22.3^{\circ} \mathrm{C}$, and the minimum temperature was $8.6^{\circ} \mathrm{C}$.

Therefore, we suggest that the environmental conditions affect in similar ways to all the exhibited artworks as the conditions of the Convent of San Francisco are similar to the ones of San Agustin. It should be highlighted that the values of RH and temperature are adequated for the activation and maintenance of alteration focus caused by microorganisms, both in the reverse and obverse of the artworks, which does not occur in more controlled places.

With respect to the illuminance, the proper value for the exhibition of canvas paintings is in the range of 150-200 Lux, advising never to exceed 500 lux as a general basic rule. ${ }^{49,50}$ The excess of illumination affects not only to the pigments of the polychromies, but also alters their organic materials and makes them prone to microbial deterioration.

In $38.77 \%$ of the measurements achieved, the illuminance was higher than 180 lux, exceeding the recommended levels. The average in the courtyard of the main cloister of the Convent of San Francisco was 486.99 lux, and the side with the highest average level was the west ground floor, with 674.85 lux, while the east ground floor registered the lowest average (326.26 lux), being all the values higher than the ones recommended.

The light intensity of the upper floor presents a marked difference compared to the rest. The average maximum illuminance levels to which the works are exposed is 5167.78 lux, with peaks on the north floor that exceed 7000 lux. These values, maintained throughout the year by the constancy of the equatorial climate, are unfeasible for the conservation of the materials of any canvas painting. They favor biodeterioration processes and have produced the cumulative and irreversible discoloration of pigments and binders, which can worsen in a few decades under these conditions. ${ }^{8}$

Because of the location of these worship buildings, in the center of a huge city, environmental pollution also presents potential capacity to activate biodeterioration processes, taking into account that their effects are different in diverse biological microbiota, ${ }^{44,45,51}$ although it is a difficult factor to monitor and control.

\section{Microbiological Study}

\section{Bacteria}

The results of the study are summarized in Table 3 . We isolated three bacteria strain from the obverse of the artwork SF2, one identified as Bacillus pumilus and the other two as Bacillus sp. Bacteria growth was not reported in the artwork SF1. In the artworks located at the Convent of Santo Domingo, we isolated five bateria: one obtained in the reverse of SD1 and identified as Bacillus subtilis and four in SD2, two in the obverse, identified as Bacillus sp. and $B a-$ cillus licheniformis, and two in the reverse: B. subtilis and Staphylococcus capitis. Finally, in the canvas "Divina Pastora" (Convent of Santa Clara, SC1), we isolated two bacterial strains, one in the obverse (Priestia megaterium, a species closely related with the genus Bacillus) and another in the reverse (Bacillus mojavensis).

\section{Fungi}

The microbiological analysis results are shown in Tables 4 and 5. In the artworks of the Convent of 


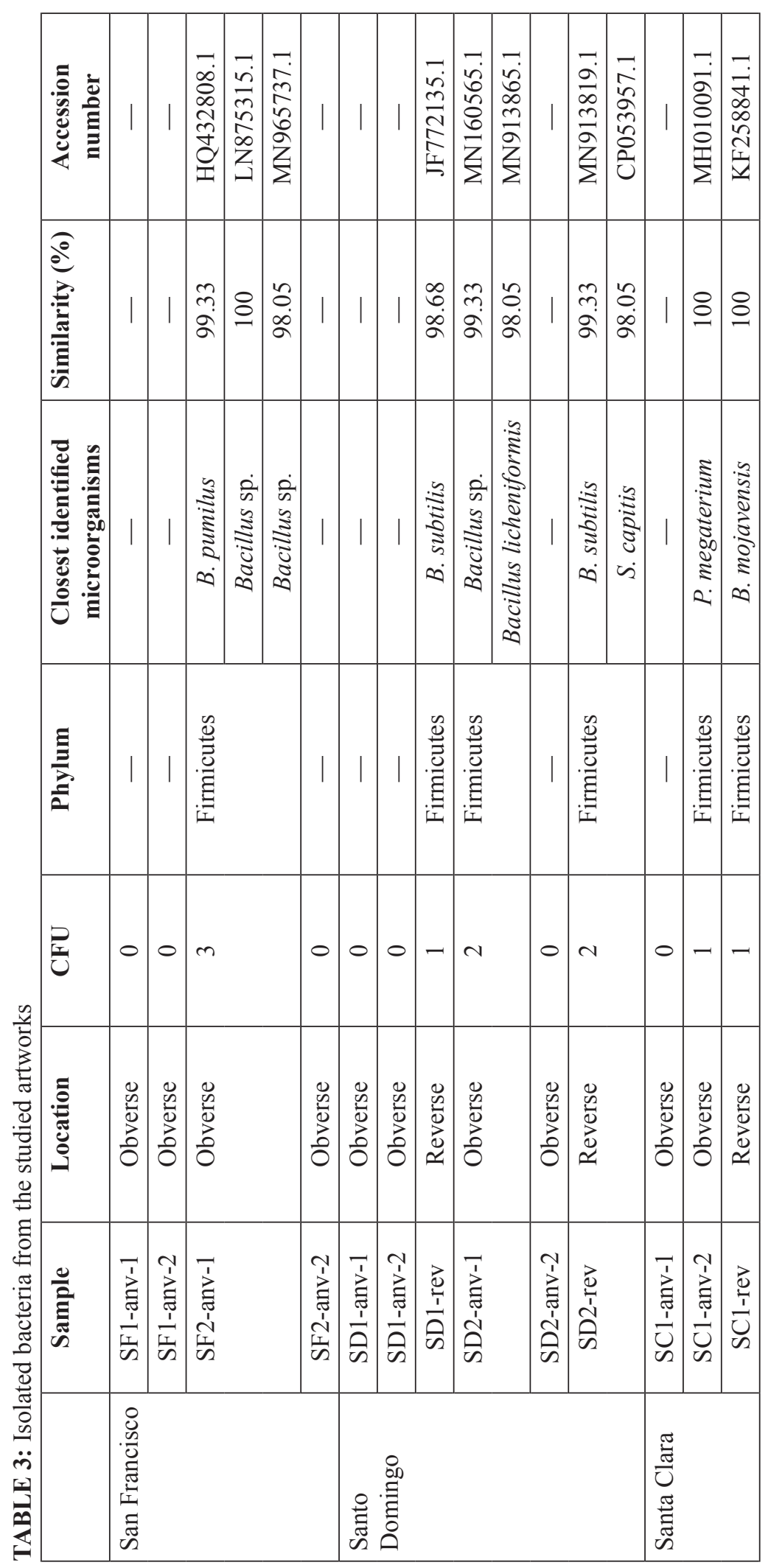


TABLE 4: Isolated fungi from the studied artworks

\begin{tabular}{|c|c|c|c|}
\hline & Sample & CFU (per swab) & Isolated fungi \\
\hline \multirow[t]{9}{*}{ San Francisco } & SF1-anv-1 & 1 & SF1-1 Alternaria sp. \\
\hline & SF1-anv-2 & 0 & - \\
\hline & \multirow[t]{5}{*}{ SF2-anv-1 } & \multirow[t]{5}{*}{5} & SF2-1 U. chartarum $(\mathrm{PCR})$ \\
\hline & & & SF2-2 Penicillium sp. \\
\hline & & & SF2-3 Alternaria sp. \\
\hline & & & SF2-4 Alternaria $s p$ \\
\hline & & & SF2-5 P. rubens (PCR) \\
\hline & \multirow[t]{2}{*}{ SF2-anv-2 } & \multirow[t]{2}{*}{2} & SF2-6 Candida $\mathrm{sp.}$ \\
\hline & & & SF2-7 Aspergillus sp. \\
\hline \multirow[t]{15}{*}{ Santo Domingo } & SD1-anv-1 & 1 & SD1-1 Mucor sp. \\
\hline & SD1-anv-2 & 1 & SD1-2 A. niger \\
\hline & SD1-rev & 0 & - \\
\hline & \multirow[t]{6}{*}{ SD2-anv-1 } & \multirow[t]{6}{*}{6} & SD2-1 Mucor sp. \\
\hline & & & SD2-2 A. alternata \\
\hline & & & SD2-3 Fusarium sp. \\
\hline & & & SD2-4 Penicillium sp. \\
\hline & & & SD2-5 E. nigrum (PCR) \\
\hline & & & SD2-6 Aspergillus sp. \\
\hline & \multirow[t]{2}{*}{ SD2-anv-2 } & \multirow[t]{2}{*}{2} & SD2-7 Mucor sp. \\
\hline & & & SD2-8 Cladosporium sp. \\
\hline & \multirow[t]{4}{*}{ SD2-rev } & \multirow[t]{4}{*}{4} & SD2-9 A. alternata \\
\hline & & & SD2-10 Fusarium sp. \\
\hline & & & SD2-11 Penicillium sp. \\
\hline & & & SD2-12 Aspergillus sp. \\
\hline \multirow[t]{7}{*}{ Santa Clara } & \multirow[t]{4}{*}{ SC1-anv-1 } & \multirow[t]{4}{*}{4} & SC1-1 C. savoryi (PCR) \\
\hline & & & SC1-2 Fusarium sp. \\
\hline & & & SC1-3 Paecilomyces sp. \\
\hline & & & SC1-4 Cladosporium sp. \\
\hline & SC1-anv-2 & 1 & SC1-5 Penicillium $s p$ \\
\hline & \multirow[t]{2}{*}{ SC1-rev } & \multirow[t]{2}{*}{2} & SC1-6 Rhizopus sp. \\
\hline & & & SC1-7 Fusarium sp. \\
\hline
\end{tabular}

San Francisco we isolated seven filamentous fungi and a yeast. We identified Alternaria sp. in SF1, and the other six were observed on the obverse of SF2: species of genera Penicillium, Alternaria and Aspergillus, the species Uloclaudium chartarum and Penicillium rubens identified by PCR, as well as a yeast compatible with the genus Candida.
In the paintings belonging to the Convent of Santo Domingo, we isolated fourteen filamentous fungal strains: two obtained on the obverse of SD1, identified as Mucor sp. and Aspergillus niger, and 12 on SD2. Eight were found on its obverse: species of genera Mucor, Fusarium, Penicillium, Aspergillus, and Cladosporium and the species Epicoccum 
TABLE 5: Fungi PCR results from the studied artworks

\begin{tabular}{|c|c|c|c|c|c|c|}
\hline & Sample & Location & Phylum & $\begin{array}{l}\text { Closest identified } \\
\text { microorganisms }\end{array}$ & $\begin{array}{c}\text { Similarity } \\
(\%)\end{array}$ & $\begin{array}{c}\text { Accession } \\
\text { number }\end{array}$ \\
\hline \multirow[t]{6}{*}{ San Francisco } & \multirow[t]{4}{*}{ SF2-1 } & \multirow[t]{4}{*}{ Obverse } & \multirow[t]{4}{*}{ Ascomycota } & Ascomycota sp. & 100 & KP698351.1 \\
\hline & & & & Pleosporaceae sp. & 100 & KX100396.1 \\
\hline & & & & Ulocladium sp. & 100 & LN808950.1 \\
\hline & & & & U. chartarum & 100 & JQ585683.1 \\
\hline & \multirow[t]{2}{*}{ SF2-5 } & \multirow[t]{2}{*}{ Obverse } & \multirow[t]{2}{*}{ Ascomycota } & Penicillium sp. & 98.07 & MT548782.1 \\
\hline & & & & P. rubens & 98.07 & MT558923.1 \\
\hline \multirow{5}{*}{$\begin{array}{l}\text { Santo } \\
\text { Domingo }\end{array}$} & \multirow[t]{5}{*}{ SD2-5 } & \multirow[t]{5}{*}{ Obverse } & \multirow[t]{5}{*}{ Ascomycota } & Dothidiomycetes sp. & 100 & KY436096.1 \\
\hline & & & & Pleosporaceae sp. & 100 & KX148616.1 \\
\hline & & & & Didymellaceae sp. & 100 & MK782277.1 \\
\hline & & & & Epicoccum sp. & 100 & MK953943.1 \\
\hline & & & & E. nigrum & 100 & MT441593.1 \\
\hline \multirow[t]{4}{*}{ Santa Clara } & \multirow[t]{4}{*}{ SC1-1 } & \multirow[t]{4}{*}{ Obverse } & \multirow[t]{4}{*}{ Ascomycota } & Fungal endophyte sp. & 100 & FM200458.1 \\
\hline & & & & Sordariomycetes sp. & 98.46 & KT264665.1 \\
\hline & & & & Coniochaeta sp. & 99.43 & KT823770.1 \\
\hline & & & & C. savoryi & 98.34 & MF161088.1 \\
\hline
\end{tabular}

nigrum identified by PCR. On the reverse, we isolated species of genera Fusarium, Penicillium and Aspergillus, and the specie Alternaria alternata.

Finally, in the painting of the Santa Clara Convent marked SC1 (Divina Pastora), seven strains of filamentous fungi were isolated, five on the obverse, corresponding to the genus: Fusarium, Paecilomyces, Cladosporium and Penicillium, and the species Coniochaeta savoryi, identified by PCR; and two fungi on its reverse, belonging to the genus Rhizopus and Fusarium.

\section{Analysis of the Microbial Diversity in the Artworks and Deterioration Factors}

In general, our results agree with the literature data, since the most bacteria and fungi isolated from the studied artworks have been previously described as common in paintings and others polychromed works of art. ${ }^{21,22,52-56}$

In the case of the bacteria, the most often identified genus (five out of seven) were Bacillus-related species, and the isolated fungi are ubiquitous microorganisms that belong to very common genus. Both groups, Bacillus and fungi, have the capability to produce spores, which allow them to resist unfavorable environmental conditions. The high levels of RH and the conditions of high-water activity maintained for long periods because of the climate of Quito, the abundance of nutrients due to deficient conservation state of the paintings and the outdoor exposure conditions are propitious to promote bacterial and fungal growth, ${ }^{57,58}$ and even to produce the development of a biofilm. ${ }^{14}$

However, the detection of airborne bacteria and fungi in a painting does not mean that all founded microorganisms are able to induce biodeterioration. In the case of the studied artworks, most of the microorganisms have been isolated in the surface, an area that although is susceptible to microbial colonization, it is a restrictive substrate, and only those microorganisms with some metabolic (presence of hydrolyzing enzymes) and physiological (production of spores, resistance to shortage of nutrients, resistance to xeric environments, etc.) capabilities may survive, grow and produce alterations in pictorial materials. ${ }^{59,60}$

These requirements coincide with the physiological characteristics of some microorganisms detected in this study. The identified spore-forming 
bacteria such as species of genera Bacillus have been frequently isolated in easel paintings ${ }^{19,21,22,14,61}$ or paper materials. ${ }^{38}$ The capacity of producing spores allows them to maintain viability in dry conditions for a long period of time. ${ }^{62}$ We should highlight their enzymatic activity. Species of genera Bacillus usually present $\beta$-glucosidase activity, an enzyme involved in the total hydrolysis of the cellulose. . $^{21,63,64}$ That is why they could have taken active part in the biodeterioration of the studied artworks. Moreover, the strains of this genus have been isolated in the reverse of the canvas, with cellulosic nature, and also in the obverse, where there are areas with loss of the pictorial and preparation layer.

In the case of the fungi, the most usual isolated microorganisms have been species of genera Alternaria and Penicillium (five strains in each case). Alternaria sp. is considered to be one of the main biodeterioration agents in paintings, due to its resistance to outdoor conditions and its ability to produce cellulase. These enzymes are also produced by other members of the Ascomycota, such as many species of Aspergillus, ${ }^{64,65}$ genus that have been isolated in four strains.

The species of genera Penicillium have been also described in articles considering mural and panel paintings, ${ }^{19,61,66}$ canvas $^{20}$ and paper. ${ }^{38}$ Penicillium has been reported as the most frequently found fungal genus in indoor air and buildings, ${ }^{67}$ which indicates its capacity for colonization and survival in many materials.

We also detect the presence of yeasts compatibles with Candida sp. Yeasts are not uncommon in mural paintings or frescos, particularly on damp cellulosic materials, due to the saprobiotic ability of many species present in the air. Dermatophyte fungi, such as species of genera Candida are generally associated as opportunistic pathogens in human skin. ${ }^{68}$ Other yeast-related species have also been identified, such as $C$. savoryi or E. nigrum. The latter has been isolated from various types of cultural assets and is resistant to environmental conditions, producing pigments, ranging from darker oranges to yellows and greens, which can interfere with the pictorial layer. ${ }^{69}$

The presence of Ulocladium chartarum can be considered as a marker of the presence of inadequate levels of RH maintained over time, since this fungus is frequently isolated from cellulosic materials damaged by moisture, such as wood and paper. ${ }^{70}$

The enzymatic activity of the microorganisms described is not limited to cellulosic materials, but also affects the constituents on the surface of paintings. The most widespread enzymatic activities related to biodeterioration were, among bacterial and fungi belonging to species of genera Bacillus and Penicillium, esterase and lipase activities. ${ }^{21}$ Both enzymes enable to catalyze the hydrolysis of the triglycerides, so they might take part in the degradation of painting binders such as linseed oil. Likewise, microorganisms belonging to the genus Penicillium and Bacillus have shown alteration ability in the terpenoid resins employed traditionally as protection varnishes, ${ }^{24-27}$ which constitutes an additional point in order to assess the risk of biodeterioration on the studied paintings.

Finally, the presence of bacteria and fungi together in the artwork can suppose a symbiotic factor for the development of biodeterioration processes. It has been described that the presence of bacterial cells can favor survival of fungi with N-acetyl-b-glucosaminidase activity, ${ }^{21}$ like Penicillium sp., because the enzyme may participate in the hydrolysis of the bacterial peptidoglycan, rendering monosaccharides capable of supporting fungal growth from dead bacterial cells.

\section{CONCLUSIONS}

The exhibition and conservation conditions of a set of pictorial works on canvas from three cloisters of the Historic Center of Quito have been analyzed. The conclusions of the study indicate that the exposure conditions of canvas paintings exhibited in external environments in a semi-tropical or equatorial climate could be risky for the artworks.

The significant fluctuations of RH in daily and seasonal cycles are very harmful to pictorial works composed of stratified materials, which react differently to changes in external conditions, compromising the stability and cohesion of the entire artwork. The illuminance values are very inadequate and far exceed those recommended, altering the studied materials from a chemical point of view (support, 
Poyatos-Jiménez et al.

binders and varnishes) and discoloring the pigments of the pictorial layer.

The high levels of RH maintained over the time allow the proliferation of fungi and bacteria. The research reveals the variety of the isolated species. The genus with more presence in the studied paintings have been Bacillus, Alternaria, and Penicillium (five strains), Aspergillus and Fusarium (four strains), Mucor (three strains), and Cladosporium (two strains). Some of the isolated microorganisms are associated to a metabolic activity that can allow the alteration of various types of pictorial materials, belonging to the support, pictorial layer or protective varnishes. Therefore, we can suggest that these microorganisms could have been active deterioration agents, contributing to the alterations observed in the paintings.

Most of the isolated microorganisms are common and respond to the patterns described in literature about microbial communities associated with exposed indoor paintings. Differential patterns have not been described at the moment due to the semitropical climate and the special exhibition conditions of the studied artworks. The significant presence of bacteria can be considered typical of this type of environmental conditions, since they require higher levels of water activity than those necessary in the case of fungi. Moreover, it does not usually occur in controlled spaces, such as conventional museums.

It should be mentioned that as some of the identification studies have been carried out exclusively from cultures, it is possible that there are spores of other microorganisms that have not been developed in vitro, but that can be activated under favorable conditions in the cloister environment. In indoor ambients, the biodeterioration processes are more often starting from the reverse of the paintings because of the abundance of nutrients and moisture in the space between the canvas and the wall. However, under exposure conditions such as those described, the opposite may occur, as a consequence of the high amount of airborne microorganisms deposited on the painted surface and high RH environments stable over the time.

For all these reasons, it is essential to establish a preventive conservation program to ensure the stability of the exhibit artworks on display. This program should include a daily control of environmental conditions and maintenance of the paintings, including a periodic superficial cleaning of the obverse, reverse and protection frames, as well as a sounding of the capillarity or filtration humidity linked to the walls. To avoid superficial deposits, it is also important to properly tension the canvases to the frames, as well as to control the stability of the woods that make them up. Restoration works are highly recommended in the paintings belonging to the Convent of San Francisco. Although they have been restored in the past, their conservation state and the wicked evolution of the treatments demand urgent improvements.

Regarding the $\mathrm{RH}$ and temperature conditions, their control is almost impossible in current conditions, due to the open exhibition spaces and the large format of the paintings. As a first preventive step, it is essential to control these parameters by data logger systems with capacity of continuos storage to detect levels of RH higher than $70 \%$ and fluctuations higher than $25 \%{ }^{71}$ The possible solutions to the serious environmental problems described are of great significance, such as the glazing of the cloisters, always avoiding the use of urns or systems that completely isolate the works from the surrounding environment, and the installation of HVAC conditioning systems if it is possible due to the maximum protection gave to these cloisters. Relocation of works indoors could also be considered, at least during the wet season.

The search for solutions to avoid the incidence of light radiation could be more complicated. In this sense, it is recommended to find spaces with no direct light exposure and not excessively windy, to avoid loosening of the canvas and superficial erosions. Ideally, if the cloisters were glazed, the installation of UV filters could be studied. We should take into account the quality, quantity and time of exposure of the works to natural light radiation, which causes cumulative and irreversible damage to the paintings.

Also, specialized training for employees in controlling these parameters and in handling works is essential in order to apply the recommended procedures as effectively as possible and extend 
the preventive biodeterioration care of the studied artworks to all the cloisters of the Monasteries of Quito.

\section{ACKNOWLEDGMENT}

The research presented here was supported by the SENESCYT Prometeo Project, Secretary of Higher Education, Science, Technology and Innovation, Ecuador.

\section{REFERENCES}

1. Centro del Patrimonio Mundial de la UNESCO [homepage on the Internet]. Expediente de Candidatura de la Ciudad de Quito a la Lista del Patrimonio Mundial. 1978 [cited 2019 Aug 19]. Available from: http://whc.unesco. org/en/list/2.

2. Zambrano I. La cuestión de la conservación del patrimonio mueble de San Francisco. Anales de la Universidad Central de Ecuador. 2015;373:493-510.

3. Poyatos-Jiménez F, Benítez J, Morales F, Giordano, A. Estudio y análisis de los procesos de alteración microbiológica en pintura sobre lienzo: Aplicaciones al patrimonio quiteño. Quito, Ecuador: UNESCO; 2016.

4. Mercé J, Silva M. Plan director de restauración. Convento e iglesia de San Francisco. Volumen II y III. Quito, Ecuadaor: Instituto Nacional de Patrimonio Cultural; 2004.

5. Sandoval Ruíz A. Plan de Gestión para el Conjunto Conventual de San Francisco de Quito. Anales de la Universidad Central de Ecuador; 2015.

6. Allsopp D, Seal K, Gaylarde C. Introduction to biodeterioration. Cambridge: Cambridge University Press; 2004.

7. Koestler RJ, Koestler VH, Charola AE, Nieto-Fernandez FE. Art, biology, and conservation: Biodeterioration of works of art. New Haven, CT: Yale University Press; 2004.

8. Michalsky S. The ABC method: A risk management approach to the preservation of cultural heritage. Ottowa, Canada: Canadian Conservation Institute (CCI); 2016.

9. Barba Merizalde CE. Conservación preventiva en los museos de la ciudad de Quito: Diagnóstico y propuesta de un plan mínimo. Quito, Ecuador: Universidad Tecnológica Equinoccial; 2004.

10. Poyatos-Jiménez F, Morales R, Cevallos L, Freile C, Morales F. Estudio y análisis de los procesos de alteración por agentes microbiológicos en obras pictóricas sobre lienzo expuestas en claustros de conventos y monasterios del centro histórico de Quito, Ecuador. Madrid, Spain: Ministerio de Educación y Cultura; 2017.

11. Caneva G, Nugari MP, Salvadori O. Plant Biology for cultural Heritage. Biodeterioration and Conservation. Los Ángeles, CA: Getty Conservation Institute; 2009.

12. Ciferri O, Tiano P, Mastromei G. Of microbes and art: The role of microbial communities in the degradation and protection of cultural heritage. Florence, Italy: Springer Science \& Business Media; 2000.

13. Ciferri O. Microbial degradation of paintings. Appl Environ Microb. 1999;65:877-85.

14. Gorbushina AA, Heyrman J, Dorniedena T, Gonzalez-Delvalle M, Krumbein WE, Laiz L, Petersen K, SaizJimenez C, Swings J. Bacterial and fungal diversity and biodeterioration problems in mural painting environments of St. Martins church (Greene-Kreiensen, Germany). Int Biodeter Biodegr. 2004;53:13-24.

15. Poyatos-Jiménez F. Procesos de biodeterioro en pinturas sobre lienzo del Museo de Bellas Artes de Granada: Examen visual y gráfico. Granada, Spain: Universidad de Granada; 2007.

16. Urzi C, de Leo F. Evaluation of the efficiency of water-repellent and biocide compounds against microbial colonization of mortars. Int Biodeter Biodegr. 2007;60(1):25-34.

17. Scheerer S, Ortega-Morales O, Gaylarde C. Microbial deterioration of stone monuments an updated overview. Adv Appl Microbiol. 2009;66:97-139.

18. Doménech-Carbó MT, Osete-Cortina L, de la Cruz Cañizares J, Bolívar-Galiano F, Romero-Noguera J, Fernández-Vivas MA, Martín-Sánchez I. Study of the microbiodegradation of terpenoid resin-based varnishes from easel painting using pyrolysis-gas, chromatography-mass spectrometry and gas chromatography-mass spectrometry. Anal Bioanal Chem. 2006;385(7):1265-80.

19. Capodicasa S, Fedia S, Porcellia AM, Zannon D. The microbial community dwelling on a biodeteriorated 16th century painting. Int Biodeter Biodegr. 2010;64:722-33.

20. Vukojević J, Ljaljević Grbić M. Moulds on paintings in Serbian fine art museums. African J Microbiol Res. 2010;4(13):1453-6.

21. López-Miras MM, Martín I, Yebra A, Romero-Noguera J, Bolívar F, Ettenauer J, Sterflinger K, Píñar G. Contribution of the microbial communities detected on an oil painting on canvas to its biodeterioration. PLoS One. 2013;8(11):e80198.

22. López-Miras MM, Piñar G, Romero-Noguera J, Bolívar FC, Ettenauer J, Sterflinger K, Martín I. Microbial communities adhering to the obverse and reverse sides of an oil painting on canvas: Identification and evaluation of their biodegradative potential. Aerobiología. 2013;29:301-14.

23. Sterflinger K, Piñar G. Microbial deterioration of cultural heritage and works of art. Tilting at windmills? Appl Microbiol Biotechnol. 2013;97(22):9637-46.

24. Romero-Noguera J, Bolívar-Galiano FC, Ramos-López JM, Fernández-Vivas MA, Martín-Sánchez I. Study of biodeterioration of diterpenic varnishes used in art painting: Colophony and Venetian turpentine. Int Biodeter Biodegr. 2008;62(4):427-33. 
25. Ramos-López JM, Bolívar-Galiano FC. Biodeterioration patterns found in dammar resin used as art material. Electron J Biotechnol. 2010;13(3):6-7.

26. Romero-Noguera J, López-Miras MM, Martín-Sánchez I, Ramos-López JM, Bolívar-Galiano FC. An approach to the study of the fungal deterioration of a classical art material: Mastic varnish. Electron J Biotechn. 2010;13(6):1-2.

27. Romero-Noguera J, Doménech-Carbó MT, Osete-Cortina L, Martín-Sánchez I, Bolívar-Galiano FC. Analytical characterisation of the biodeterioration of diterpenoid labdanic varnishes used in pictorial techniques: Sandarac and Manila copal. Int Biodeter Biodegr. 2014;90:99-105.

28. Sáiz-Jiménez C. Deposition of airborne organic pollutants on historic buildings. Atmos Environ. 1993;27:77-85.

29. Strzelczyk AB. Paintings and sculptures. In: Microbial deterioration. London: Rose Academic Press; 1981.

30. Schabereiter-Gurtner C, Piñar G, Lubitz W, Rölleke S. An advanced strategy to identify bacterial communities on art objects. J Microbiol Meth. 2001;45:77-87.

31. Poyatos F, Morales F, Nicholson AW, Giordano A. Physiology of biodeterioration on canvas paintings. J Cell Physiol. 2018;233(4):2741-51.

32. Soliman NA, Knoll M, Abdel-Fattah YR, Schmid RD, Langeb S. Molecular cloning and characterization of thermostable esterase and lipase from Geobacillus thermoleovorans YN isolated from desert soil in Egypt. Process Biochem. 2007;42(7):1090-1100.

33. Alakomi HL, Paananen A, Suihko ML, Helander IM, Saarela M. Weakening effect of cell permeabilizers on Gram negative bacteria causing biodeterioration. Appl Environ Microbiol. 2006;72:469-73.

34. Suihko ML, Alakomi HL, Gorbushina A, Fortune I, Marquardt J, Saarela M. Characterization of aerobic bacterial and fungal microbiota on surfaces of historic Scottish monuments. Syst Appl Microbiol. 2007;30:494-508.

35. INPC. Convento de San Francisco después del terremoto de 1868. [monograph on the Internet]. Quito Pichincha Ecuador: Archivo Nacional de Fotografía [cited 2019 Mar 14]. Available from: http://fotografiapatrimonial.gob.ec/ web/es/galeria/element/5539; 2015.

36. Gil-Muñoz MT, Enríquez de Salamanca GE. Seguimiento y control de las condiciones microclimáticas en lugares de culto. Madrid, Spain: Ministerio de Educación, Cultura y Deporte; 2012.

37. Villamar V. Registro de condiciones ambientales en el patio del claustro principal del convento de San Francisco y su relación con los deterioros presentes en las obras expuestas. Quito, Ecuador: Universidad Tecnológica Equinoccial; 2015.

38. Michaelsen A, Piñar G, Montanari M, Pinzari F. Biodeterioration and restoration of a 16th-century book using a combination of conventional and molecular techniques: A case study. Int Biodeter Biodegr. 2009;63:161-8.

39. Samson RA, Hoekstra ES, Frisvad JC. Introduction to food-borne fungi, 7th edition. Utrecht, the Netherlands: Centraalbureau voor Schimmelcultures; 2004.

40. Carrillo, L. Claves para la identificación de los hongos de los alimentos y forrajes. Salta, Argentina: Universidad Nacional de Salta; 2011.

41. Sert B, Sterflinger KA. A new Coniosporium species from historical marble monuments. Mycol Progress. 2009;9:353-9.

42. White TA, Bruns T, Lee S, Taylor J. Amplification and direct sequencing of fungal ribosomal RNA genes for phylogenetics. In PCR protocols. Cambridge, MA: Academic Press; 1990. p. 315-22.

43. BLAST [database on the Internet]. Basic Local Alignment Search Tool (BLAST). Bethesda, MD: National Center for Biotechnology Information [cited 2019 Sep 14]. Available from: http://www.ncbi.nlm.nih.gov/BLAST/.

44. ASHRAE. Heating, ventilating, and air-conditioning applications. Museums, libraries and archives. Atlanta, GA: American Society of Heating Refrigerating and Air-Conditioning Engineers; 2003.

45. ASHRAE. Heating, ventilating, and air-conditioning systems and equipment. ASHRAE Handbook. Atlanta, GA: American Society of Heating Refrigerating and Air-Conditioning Engineers; 2008.

46. Thompson, G. Museum environment. 2nd ed. Oxford: Butterworth-Heinemann Series in Conservation and Museology; 1994.

47. Pedersoli JL, Antomarchi C, Michalski S. A guide to risk management of cultural heritage. Rome: International Centre for the Study of the Preservation and Restoration of Cultural property (ICCROM); 2016.

48. Saltos E. Incidencia de los factores ambientales en las obras atribuidas a Miguel de Santiago ubicadas en el claustro del convento San Agustín. Quito, Ecuador: Universidad Tecnológica Equinoccial; 2014.

49. Boylan PJ. Running a museum: A practical handbook [monograph on the Internet]. Canadian Conservation Institute; 2004 [cited 2019 Oct 16]. Available from: https:// www.canada.ca/en/conservation-institute.html.

50. Herráez JA, Enríquez de Salamanca G, Pastor Arenas MJ, Gil Muñoz T. Manual de seguimiento y análisis de condiciones ambientales. Madrid, Spain: Ministerio de Educación, Cultura y Deporte; 2014.

51. Grzywacz CM. Monitoring for gaseous pollutans in museums environments: Tools for conservation. Los Angeles, CA: The Getty Conservation Institute; 2006.

52. Santos A, Cerrada A, García S, San Andrés M, Abrusci C, Marquina D. Application of molecular techniques to the elucidation of the microbial community structure of antique paintings. Microb Ecol. 2000;58:692-702.

53. Okpalanozie OE, Adebusoye SA, Troiano F, Polo A, Cappitelli F, Ilori MO. Evaluating the microbiological risk to a contemporary Nigerian painting: Molecular and biodegradative studies. Int Biodeter Biodegr. 2016;114:184-92. 
54. Sanmartín P, De Araujo A, Vasanthakumar A. Melding the old with the new: Trends in methods used to identify, monitor and control microorganisms on cultural heritage materials. Microb Ecol. 2018;76:64-80.

55. Paiva de Carvalho H, Sequeira SO, Pinho D, Trovao J, da Costa RMF, Egas C, Macedo MF, Portugal A. Combining an innovative non-invasive sampling method and high-throughput sequencing to characterize fungal communities on a canvas painting. Int Biodeter Biodegr. 2019; 145:104816.

56. Pínar G, Poyntner C, Lopandic K, Tafer H, Sterflinger K. Rapid diagnosis of biological colonization in cultural artefacts using the MinION nanopore sequencing technology. Int Biodeter Biodegr. 2020;148:104908.

57. Garg KL, Kamal KJ, Mishra AK. Role of fungi in the deterioration of wall paintings. Sci Total Environ. 1995;167:255-71.

58. Grabek-Lejko D, Tekiela A, Kaspryk I. Risk of biodeterioration of cultural heritage objects, stored in the historical and modern repositories in the Regional Museum in Rzeszow (Poland). A case study. Int Biodeter Biodegr. 2017;123:46-55.

59. Möhlenhoff P, Müller L, Gorbushina AA, Petersen K. Molecular approach to the characterisation of fungal communities: Methods for DNA extraction, PCR amplification and DGGE analysis of painted art objects. FEMS Microbiol Lett. 2001;195:169-73.

60. Dar SA, Kuenen JG, Muyzer G. Nested PCR-denaturing gradient gel electrophoresis approach to determine the diversity of sulphate reducing bacteria in complex microbial communities. Appl Environ Microb. 2005;71:2320-30.

61. Pepe O, Sannino L, Palomba S, Anastasio M, Blaiotta G, Villani F, Moschetti G. Heterotrophic microorganisms in deteriorated medieval wall paintings in southern Italian churches. Microbiol Res. 2010;165:21-32.

62. Karbowska-Berent J, Górny RL, Strzelczyka AB, Agnieszka W. Airborne and dust borne microorganisms in selected Polish libraries and archives. Build Environ. 2011;46(10):1872-9.

63. Priest G. Extracellular enzyme synthesis in the genus Bacillus. Bacteriol Rev. 1977;41:711-53.

64. Cellulolytic Enzyme Database (CelDB) [database on the Internet]. [cited 2019 Oct 16]. Available from: http:// www.microbiome.re.kr/db/celdb/.

65. Radaelli A, Paganini M, Basavecchia V, Elli V, Neri M, Zanotto C, Pontieri E, De Giuli Morghen C. Identification, molecular biotyping and ultrastructural studies of bacterial communities isolated from two damaged frescoes of St Damians Monastery in Assisi. Lett Appl Microbiol. 2004;38:447-53.

66. Piñar G, Ripka K, Weber J, Sterflinger K. The micro-biota of a sub-surface monument the medieval chapel of St. Virgil (Vienna, Austria). Int Biodeter Biodegr. 2009;63:851-9.

67. Hyvarinen, A. Characterizing moisture damaged buildings environmental and biological monitoring. National Public Health Institute; 2002.

68. Guglielminetti M, Morghen CD, Radaelli A, Bistoni F, Carruba G, Spera G, Caretta G. Mycological and ultrastructural studies to evaluate biodeterioration of mural paintings. Detection of fungi and mites in Frescos of the monastery of St Damian in Assisi. Int Biodeter Biodegr. 1994;33(3):269-83.

69. Stupar M, Grbić ML, Džamić A, Unković N, Ristić M, Jelikić A, Vukojević J. Antifungal activity of selected essential oils and biocide benzalkonium chloride against the fungi isolated from cultural heritage objects. S African J Bot. 2014;93:118-24.

70. Samson RA, Olaf CG, Adan OCG. Fundamentals of mold growth in indoor environments and strategies for healthy living. Wageningen, the Netherlands: Wageningen Academic Publishers: 2011.

71. Gil-Muñoz MT, Enríquez de Salamanca GE. Seguimiento y control de las condiciones microclimáticas en lugares de culto. Madrid, Spain: Ministerio de Educación, Cultura y Deporte; 2012. 